\title{
The correlations of serum interleukin-6 (il-6) levels and serum soluble il-6 receptor levels with disease activity in systemic juvenile idiopathic arthritis patients with and without tocilizumab treatment
}

\author{
Butsabong Lerkvaleekul, , Sirisucha Soponkanaporn, Soamarat Vilaiyuk \\ From 21st European Pediatric Rheumatology (PReS) Congress \\ Belgrade, Serbia. 17-21 September 2014
}

\section{Introduction}

Interleukin-6 (IL-6) and soluble IL-6 receptor (sIL-6R) have been demonstrated to play a significant role as inflammatory mediators in systemic juvenile idiopathic arthritis (SJIA). Tocilizumab, a humanized anti-IL-6 receptor antibody, becomes a new biologic treatment for SJIA nowadays but the correlation of serum IL-6 levels and serum sIL-6R levels with disease activity in SJIA with and without tocilizumab treatment are still unclear.

\section{Objectives}

To determine the correlations of serum IL- 6 levels and serum sIL-6R levels with disease activity in SJIA patients with and without tocilizumab treatment

\section{Methods}

SJIA patients in pediatric rheumatology clinic, Ramathibodi hospital between September 2011 and June 2013 were enrolled in this study. Patients were followed up three times in 2-3 months interval. Fifteen healthy children were included as normal controls. Demographic data was collected. During the visit, patients were evaluated according to Juvenile Arthritis Disease Activity Score-71 (JADAS-71) and blood samplings were collected for complete blood count, erythrocyte sedimentation rate, IL-6 levels, and sIL-6R levels, then patients were categorized into 4 groups; 1 ) active disease with systemic features and arthritis 2) active disease with only arthritis 3 ) remission on medication 4) remission off medication

\footnotetext{
Pediatrics, Faculty of Medicine Ramathibodi Hospital, Mahidol University,
} Bangkok, Thailand

\section{Results}

Forty-two SJIA patients, 131 blood samplings were included in this study. Seventeen patients $(40 \%)$ were treated with tocilizumab during the study. Serum IL-6 levels in patients without tocilizumab treatment significantly elevated in active disease with systemic features and arthritis [median (IQR) $=101.8(303.2) \mathrm{pg} / \mathrm{mL}$ ] when compared to active disease with only arthritis $[$ median $(\mathrm{IQR})=4.5(23) \mathrm{pg} / \mathrm{mL}]$, and remission on medication [median $(\mathrm{IQR})=1.5(0.55) \mathrm{pg} / \mathrm{mL}$ ], whereas serum IL-6 levels in patients with tocilizumab treatment were not different between groups but there were significantly different when compared to healthy children $(\mathrm{p}<0.05)$. In addition, the correlation between serum IL-6 levels and JADAS-71 in patients without tocilizumab treatment $(\mathrm{r}=0.71, \mathrm{p}<0.001)$ was stronger than patients with tocilizumab treatment $(\mathrm{r}=0.42, \mathrm{p}=0.01)$. Serum sIL-6R levels in SJIA patients with and without tocilizumab treatment were significantly higher when compared to healthy children ( $\mathrm{p}<0.05)$. Interestingly, in patients with tocilizumab treatment, serum sIL-6R levels were extremely higher $[$ median $(\mathrm{IQR})=1,110.3(840.2) \mathrm{ng} / \mathrm{mL}]$ than patients without tocilizumab treatment [median $(\mathrm{IQR})=94.2$ (82.7) $\mathrm{ng} / \mathrm{mL}]$.

\section{Conclusion}

The correlation between serum IL-6 levels and disease activity in patients without tocilizumab treatment was stronger than patients with tocilizumab treatment. In addition, serum sIL-6R levels in patients with tocilizumab treatment were extremely higher than patients without tocilizumab treatment. 


\section{Disclosure of interest}

None declared.

Published: 17 September 2014

doi:10.1186/1546-0096-12-S1-P61

Cite this article as: Lerkvaleekul et al: The correlations of serum

interleukin-6 (il-6) levels and serum soluble il-6 receptor levels with

disease activity in systemic juvenile idiopathic arthritis patients with and

without tocilizumab treatment. Pediatric Rheumatology 2014 12(Suppl 1):P61.

Submit your next manuscript to BioMed Central and take full advantage of:

- Convenient online submission

- Thorough peer review

- No space constraints or color figure charges

- Immediate publication on acceptance

- Inclusion in PubMed, CAS, Scopus and Google Scholar

- Research which is freely available for redistribution

Submit your manuscript at 